\title{
PLATINUM-GROUP ELEMENT GEOCHEMISTRY OF EASTERN FINLAND KIMBERLITES AND THEIR MANTLE SAMPLE
}

\author{
Petri Peltonen \\ Geological Survey of Finland, FIN-02151, Espoo, Finland
}

\section{KIMBERLITES}

Both the diamondiferous and barren Group I kimberlites of eastern Finland are characterised by chondritic IPGE abundance ratios and slightly suprachondritic $(\mathrm{Pd} / \mathrm{Ir})_{\mathrm{N}}$. Os, Ir and Ru (IPGE) abundances are higher than in typical MORB or OIB while Pt and Pd (PPGE) are comparable. Interestingly, Finnish kimberlites have significantly bwer PGE abundances compared to both Group I and II kimberlites of southern Africa and Brasilia. All PGEs correlate with $\mathrm{Ni}$ and $\mathrm{Cr}$ suggesting derivation from a common source. However, mixing between kimberlite melt and bulk continental mantle peridotite - as represented by mantle nodules - fails to reproduce the results yielding much higher PGE values than what is observed in kimberlites. This suggests that the PGE abundances of kimberlite are mainly controlled by sulfide inclusions in xenocrystic primary mantle minerals whereas those sulfides that were originally interstitial in mantle peridotites have been removed from the magma during ascent.

\section{MANTLE XENOLITHS}

The PGE characteristics of the deep continental mantle are poorly constrained. In order to fill this gap we have analysed six PGEs and Au from 11 garnet-facies mantle nodules (lherzolites, harzburgites and dunites) and two megacrysts (olivine and clinopyroxene) from the eastern Finland kimberlite pipes. The continental mantle in that area was stabilis ed by c. $3.5 \mathrm{Ga}$ although younger reworking of the lower SCLM has been proposed. The analysed samples have been derived from a depth interval of $170-230 \mathrm{~km}$ and follow a conductive geotherm that corresponds to a surface heat flow density value of $36 \mathrm{mWm}^{-2}$. Lherzolite and harzburgite nodules have absolute $\mathrm{Os,} \mathrm{Ir} \mathrm{and} \mathrm{Ru}$ abundances slightly higher than primitive mantle (0.95$1.39 \times \mathrm{PM})$ but broadly chondritic inter-element ratios. In contrast, the PPGE (Pt and Pd) are all clearly depleted relative to IPGE. Platinum and Pd progressively decrease with decreasing indices of fertility, such as modal clinopyroxene, and whole rock
$\mathrm{Al}_{2} \mathrm{O}_{3}$ and $\mathrm{Sc}$ abundances. Those samples that are most depleted in their basaltic constituents (dunites) are depleted in all PGE, at less than $0.1 \mathrm{x}$ PM level. These features imply compatible behaviour for Os, Ir, and $\mathrm{Ru}$, but clearly incompatible behaviour for Pt and Pd during high-pressure mantle melting.

\section{RESULTS}

Compared to worldwide occurrences of shallow mantle samples (basalt-borne spinel-facies nodules and orogenic lherzolites) deep-seated garnet peridotites seem to be more depleted in their basaltic constituents and in PPGE, while IPGE abundances are comparable. Since some shallow mantle suites can in fact be variably enriched in PPGE, I suggest that this could be a manifestation of large-scale flux of PPGE from deep SCLM to shallow levels in the form of channellized and percolating melts that have precipitated PPGE-rich sulphides. Through time this process has resulted in considerable (vertical) mantle heterogeneity with respect to platinum-group element abundances and ratios.

\section{REFERENCES}

Kukkonen, I.T., Peltonen, P. 1999. Xenolith-controlled geotherm for the central Fennoscandian Shield: implications for lithosphere-astenosphere relations. Tectonophysics 304, 301-315.

O’Brien H., Tyni M., 1999. Mineralogy and geochemistry of kimberlites and related rocks from Finland. In: Gurney, J.J., Gurney, J.L., Pascoe, M.D. and Richardson, S.H. (Eds.), Proc. $7^{\text {th }}$ Int. Kimb. Conf. Vol. 2, pp. 625-636.

Peltonen, P., Kinnunen, K., Huhma, H. 2002. Petrology of two diamondiferous eclogite xenoliths from the Lahtojoki kimberlite pipe, eastern Finland. Lithos 63, 151-164.

Peltonen, P., Huhma, H., Tyni, M. \& Shimizu, N. 1999. Garnet peridotite xenoliths from kimberlites of Finland: nature of the continental mantle at an Archaean craton - Proterozoic mobile belt transition. In: Gurney, J.J., Gurney, J.L., Pascoe, M.D., Richardson, S.H. (Eds.), Proc. $7^{\text {th }}$ Int. Kimb. Conf. Vol. 2, pp. 664-676.

Contact: P. Peltonen, Geological Survey of Finland, PO Box 96, FIN-02151 Espoo, Finland, E-mail: petri.peltonen@gsf.fi 